\title{
THE ANTIOXIDANT SYSTEM ENZYMES' ACTIVITY IN RATS' BRAIN, INTOXICATED WITH SODIUM FLUORIDE IN SUBTOXIC DOSES
}

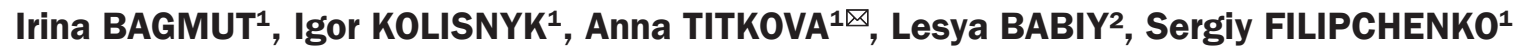 \\ ${ }^{1}$ Department of Clinical Pathophysiology, Topographic Anatomy and Operative Surgery, Kharkiv Medical \\ Academy of Postgraduate Education, Kharkiv, Ukraine \\ ${ }^{2}$ Department of Normal Anatomy, Kharkiv National Medical University, Ukraine
}

\author{
Received 09 Sept 2018, Accepted 14 Nov 2018 \\ hitps://doi.org/10.31688/ABMU.2018.53.4.03
}

\section{Abstract}

The aim of the study was to assess the activity of enzymes in the antioxidant system in the brain of rats subjected to intoxication with sodium fluoride in subtoxic doses.

Methods. The studies were conducted on sexually mature Wistar rats weighing $180-220 \mathrm{~g}$, subjected to oral exposure by means of a probe with aqueous solutions of sodium fluoride (SF) once daily for 60 days at doses of 1/10,1/100 and 1/1000 DL50, correspondingly, equaling to $20 \mathrm{mg} / \mathrm{kg}, 2 \mathrm{mg} / \mathrm{kg}$ and $0.2 \mathrm{mg} / \mathrm{kg}$ of body weight. Chemoluminescent method was used to confirm the induction of free radical processes by measuring the intensity of super-weak luminescence in the homogenate of the liver and the brain in the range of 400-600 nm, which occurs as a result of chemoluminescent reactions. Statistical analysis of the results was carried out using Statistica 6.1 (StatSoft, Inc., USA).

Results. Reducing the intensity of a superweak luminescence on the 60th day of oral administration of SF to rats at a dose of $1 / 10$ DL50 indicates a depletion of the energy potential of the substrate and the inadequate admission of free radicals of biological molecules

\section{Résumé}

Lactivité des enzymes du système antioxydant dans le cerveau des rats, intoxiqués avec du fluorure de sodium en doses subtoxiques

Le but de la recherche était d'étudier l'activité des enzymes dans le système antioxydant dans le cerveau des rats soumis à une intoxication avec du fluorure de sodium en doses subtoxiques.

Matériel et méthodes. Les études ont été menées sur des rats Wistar sexuellement matures pesant 180-220 g, soumis à une exposition orale au moyen d'une sonde avec des solutions aqueuses de fluorure de sodium (SF) une fois par jour pendant 60 jours à des doses de $1 / 10$, $1 / 100$ et DL50 1/1000, correspondant à $20 \mathrm{mg} / \mathrm{kg}, 2$ $\mathrm{mg} / \mathrm{kg}$ et $0,2 \mathrm{mg} / \mathrm{kg}$ de poids corporel. La méthode chimioluminescente a été utilisée pour confirmer l'induction du processus des radicaux libres en mesurant l'intensité de la luminescence ultra-faible dans l'homogénat du foie et du cerveau, dans la gamme de 400-600 $\mathrm{nm}$, qui se produit à la suite de réactions chimioluminescentes. L'analyse statistique des résultats a été réalisée en utilisant Statistica 6.1 (StatSoft, Inc., USA). 
to the oxidation system. The results showed a significant $(p<0.001)$ increase of chemoluminescence relative to the comparison group of animals in the induced by dual-valent iron ions in the brain of experimental group of rats, who were administered SF at a dose of $1 / 10$ DL50 on the $10^{\text {th }}$ day of observation, on average by $40 \%$.

Conclusion. Under conditions of long-term fluoride intoxication in the rat's brain, the expressed disruptions of free radical oxidation occur, which is reflected as the increase in the intensity of chemoluminescence of its homogenate and decrease in the activity of the antioxidant enzymes, superoxide dismutase and catalase, in the neocortex, which is a significant factor in the depletion of the adaptive capacity of the body.

Keywords: enzymes, antioxidant system, chemoluminescence, sodium fluoride.

\author{
Abbreviations \\ $\mathrm{SF}=$ sodium fluoride \\ $\mathrm{SOD}=$ superoxide dismutase
}

Résultats. La réduction de l'intensité d'une super luminescence au 60ème jour d'administration orale de SF à des rats à une dose de 1/10 DL50 indique une déplétion du potentiel énergétique du substrat et l'admission inadéquate de radicaux libres des molécules biologiques dans le système d'oxydation. Les résultats ont montré une augmentation significative $(p<0,001)$ de la chimioluminescence par rapport au groupe de comparaison des animaux induits par les ions de fer à double valence dans le cerveau du groupe expérimental des rats, qui ont reçu une dose de 1/10 DL50 au 10e jour d'observation, en moyenne de $40 \%$.

Conclusions. Dans les conditions d'intoxication au fluor à long terme dans le cerveau du rat, les perturbations exprimées de l'oxydation radicalaire se traduisent par l'augmentation de l'intensité de la chimioluminescence de son homogénat et la diminution de l'activité des enzymes antioxydantes, la superoxyde dismutase et la catalase, dans le néocortex, qui est un facteur important dans la deplétion de la capacité d'adaptation du corps.

Mots-clés: enzymes, système antioxydant, chimioluminescence, fluorure de sodium.

in more than 100 human pathologies. Superoxide is generated by many life processes, which include aerobic metabolism, oxidative phosphorylation and photosynthesis, in addition to the respiratory burst in the immune response of stimulated macrophages and neutrophils ${ }^{5}$. Superoxide and superoxide-dependent formation of hydroxyl radicals are important in oxygen toxicity. If unchecked, reactive oxygen species (ROS) including the superoxide radical can result in inflammation and inflict cell injury that includes DNA damage mediated by Fenton chemistry. This ROS-mediated cellular damage is implicated in many human pathologies, including ischemic reperfusion injury, cardiovascular disease, cancer, aging and neurodegenerative disease ${ }^{6}$.

The AIM OF THE STUDY was to assess the activity of enzymes in the antioxidant system in the brain of rats subjected to intoxication with sodium fluoride in subtoxic doses.

\section{Materials AND Methods}

The studies were conducted on sexually mature Wistar rats weighing 180-220 g, which were kept under steady conditions of vivarium in Kharkiv Medical Academy of Postgraduate Education (Ukraine) from 2014 till 2016. Rats were subjected to oral exposure by means of a probe with aqueous solutions of 
Table 1. Activity of superoxide dismutase and catalase in neocortex of rats under the influence of sodium fluoride in subtoxic doses $(\mathrm{n}=10 ; \mathrm{Me}[25 \% ; 75 \%]$ or $\mathrm{M} \pm \mathrm{s})$

\begin{tabular}{|c|c|c|c|}
\hline Dose & Day of observation & $\begin{array}{c}\text { Superoxide dismutase, cu/min. mg of } \\
\text { protein }\end{array}$ & Catalase, $\mu \mathrm{kat} / \mathrm{mg}$ of protein \\
\hline \multirow{5}{*}{$1 / 10$ DL50 } & 10 & $0.29 \pm 0.039 p=0.003$ & $0.13[0.11 ; 0.15] \mathrm{p}=0.140$ \\
\hline & 20 & $0.12[0.10 ; 0.16] p=0.009$ & $0.10[0.08 ; 0.11] p=0.002$ \\
\hline & 30 & $0.14[0.09 ; 0.16] p<0.001$ & $0.09[0.07 ; 0.10] p<0.001$ \\
\hline & 50 & $0.09 \pm 0.018 p<0.001$ & $0.07[0.05 ; 0.09] p<0.001$ \\
\hline & 60 & $0.10[0.06 ; 0.11] p<0.001$ & $0.05[0.04 ; 0.09] p<0.001$ \\
\hline \multirow{5}{*}{ 1/100 DL50 } & 10 & $0.31 \pm 0.041 \mathrm{p}=0.001$ & $0.16[0.14 ; 0.19] p=0.850$ \\
\hline & 20 & $0.24[0.17 ; 0.28] p=0.151$ & $0.11 \pm 0.025 p=0.019$ \\
\hline & 30 & $0.15[0.12 ; 0.18] p<0.001$ & $0.12 \pm 0.019 p<0.001$ \\
\hline & 50 & $0.15[0.13 ; 0.22] p=0.004$ & $0.09[0.07 ; 0.11] p<0.001$ \\
\hline & 60 & $0.09[0.07 ; 0.13] p=0.001$ & $0.11[0.09 ; 0.13] p<0.001$ \\
\hline \multirow{5}{*}{ Comparison group } & 10 & $0.21 \pm 0.054$ & $0.17[0.11 ; 0.21]$ \\
\hline & 20 & $0.19[0.16 ; 0.20]$ & $0.14 \pm 0.031$ \\
\hline & 30 & $0.27[0.25 ; 0.29]$ & $0.16[0.15 ; 0.20]$ \\
\hline & 50 & $0.26[0.19 ; 0.30]$ & $0.15[0.12 ; 0.17]$ \\
\hline & 60 & $0.18[0.15 ; 0.22]$ & $0.19[0.17 ; 0.23]$ \\
\hline
\end{tabular}

Note: $p$ is the level of statistical significance in relation to the comparison group

SF once daily for 60 days at doses of $1 / 10,1 / 100$ and $1 / 1000$ DL50, correspondingly, equaling to $20 \mathrm{mg} / \mathrm{kg}, 2 \mathrm{mg} / \mathrm{kg}$ and $0.2 \mathrm{mg} / \mathrm{kg}$ of body weight (average lethal dose of SF for rats, given orally, is 200 $\mathrm{mg} / \mathrm{kg}$ ). Animals of the comparison group were given appropriate amounts of drinking water. The study was conducted on the 10, 20, 30, 50 and 60 days after launching the experiment. Each group included 10 animals. Animals were euthanized by decapitation with a guillotine knife, pre-anesthetizing with sodium thiopental in a dose of $50 \mathrm{mg} / \mathrm{kg}$ of body weight.

The activity of superoxide dismutase (EC 1.15.1.1) in neocortex of the brain was evaluated spectrophotometrically by measuring the inhibition by the oxidation enzyme quercetin with molecular oxygen? ${ }^{7}$ The reaction mixture contained $50 \mathrm{mM}$ of carbonate buffer ( $\mathrm{pH}=10.0), 0.08 \mathrm{mM}$ EDTA, $0.8 \mathrm{mM}$ tetramethyl ethylenediamine. The change in optical density was recorded at $406 \mathrm{~nm}$ on SF-46.

The activity of catalase (EC 1.11.1.6) in neocortex of the brain was estimated by reducing the amount of hydrogen peroxide spectrophotometrically at $240 \mathrm{~nm}^{5}$. The reaction mixture contained $0.01 \mathrm{M}$ potassium phosphate buffer, $0.5 \mathrm{mM}$ EDTA and $15 \mathrm{mM} \mathrm{H}_{2} \mathrm{O}_{2}$.

Chemoluminescent method was used to confirm the induction of free radical processes by measuring the intensity of ultra-weak luminescence in the homogenate of the liver and the brain in the range of 400-600 nm, which occurs as a result of chemoluminescent reactions ${ }^{8,9}$. In biological systems, the quantum of light is emitted in the recombination reaction of peroxide radicals. The suppressive luminescence was fixed using fluorochrome - a chemical additive that enhances the weak spontaneous luminescence (hydrogen peroxide, dichloromethane ions). Chemoluminograms were recorded on XLM1C-01 chemoluminescenter. Measuring units of the chemoluminescope ensured the digital output of the display panel and the printing device; record of chemoluminograms on the graphic tape of the recording device; mixing of samples and reagents supplied through the dosing slot, sampling and light protection; thermostating cuvette and cooling of the photoelectric amplifier.

Statistical analysis of the results was carried out using Statistica 6.1 (StatSoft, Inc., USA).

\section{Results}

In the neocortex, as the most sensitive segment of the brain to the negative effects of chemical factors, the activity of enzymes of the first line of antioxidant protection - SOD and catalase was determined.

On the 10th day of exposure of rats in the experimental group to SF at a dose of $1 / 10$ DL50, there was a reliable $(\mathrm{p}=0.003)$, as opposed to the comparison group of animals, increase in the activity of SOD on average by $33 \%$, which can be considered as a protective and adaptive reaction of the body (Table 1). On the following observation dates, we determined a statistically significant $(\mathrm{p} \leq 0.009)$ decrease activity of the enzyme by an average of $50 \%$ in the neocortex of rats, which weakens the activity of the antioxidant system. 
The obtained results indicated a reliable decrease of catalase activity as contrasted to the comparison group in the neocortex of rats,intoxicated with SF at doses of $1 / 10$ and $1 / 100$ DL50, in all observational periods, except for the 10th day $(\mathrm{p}=0.140$ and $\mathrm{p}=0.850$, respectively) (Table 1$)$.

The study of the balance of pro- and antioxidants is essential, as a rule, for understanding its physiological role, the state of redox-homeostasis, the potential for the development of oxidative stress. The shift in balance towards increased formation of active forms of oxygen in rats under conditions of fluoride intoxication may contribute to the development of degenerative tissue damage, in particular brain tissue $^{10}$. For a more objective assessment of the effect of SF on the central nervous system, data on the state of balance of pro- and antioxidants are required. In addition, for the course of free radical reactions in the nerve tissue, there are all conditions available: the content of unsaturated fatty acids is about $52 \%$ of the dry brain balance, and the activity of antioxidant enzymes is lower than in other tissues. In addition, in the brain there are intense metabolic processes with high oxygen consumption, which are the initiator and the main participant in free radical oxidation ${ }^{11-14}$.

In experimental and clinical studies of biological tissues and homogenates for evaluation of the prooxidant-antioxidant balance under conditions of various intoxication, chemoluminescence is widely used ${ }^{15-18}$.

The results showed a significant $(\mathrm{p}<0.001) \mathrm{in}$ crease of chemoluminescence relative to the comparison group of animals in the induced by dual-valent iron ions in the brain of experimental group of rats, who were administered SF at a dose of $1 / 10$ DL50 on the 10th day of observation, on average by $40 \%$ (Table 2). At the 20th and 30th day, the intensity of chemoluminescence $(p<0.001)$ was most pronounced on average by 116 and 108\%, respectively, and on the 50 th day there was a slight decrease in relation to the previous observation periods, but it remained at the same time $(\mathrm{p}<0.001)$ increased in relation to comparison group. On the 60th day of the SF action at a dose of $1 / 10$ DL50 in the brain, as in the case of the liver, a statistically significant $(p=0.008)$ relative to the comparison group of rats, decrease in the intensity of chemoluminescence was observed on average by $18 \%$. Probably, at this stage of effect of SF at a dose of $1 / 10$ DL50, the process of free radical oxidation resolves with the formation of end products that do not undergo further peroxidation, which leads to a gradual decrease in the intensity of induced chemoluminescence in the brain homogenate of experimental animals ${ }^{19}$. However, in the literature there is an explanation of the possible decrease in the intensity of chemoluminescence by increasing the level of middle mass molecules in endotoxemia, which have the ability to bind ions of dual valency iron, depriving them from their catalytic activity, which is reflected in the stages of the course of free radical reactions ${ }^{20-21}$.

On the $10^{\text {th }}$ day of oral administration of SF in rats, at a dose of $1 / 100$ DL50, a probable $(p<0.001)$ increase of chemoluminescence was observed in contrast to the comparison group. On the $20^{\text {th }}, 30^{\text {th }}$ and $50^{\text {th }}$ days, the dynamics of changes in this indicator was characterized by an increase of almost the same level by an average of $85 \%$, and by the $60^{\text {th }}$ day, with some decrease, while remaining at an increase as opposed to the comparison group of animals at an average of $47 \%$ (Table 2).

\section{Discussion}

SOD is a master eukaryotic regulator of oxygen radicals, with relevance to brain pathology, cancer,

Table 2. Intensity of $\mathrm{Fe}^{2+-}$ induced chemoluminescence in the homogenate of the rat brain under the influence of sodium fluoride in subtoxic doses $(\mathrm{n}=10$; Me $[25 \% ; 75 \%]$ or $\mathrm{M} \pm \mathrm{s}$ )

\begin{tabular}{|c|c|c|c|}
\hline \multirow{3}{*}{ Day of observation } & \multicolumn{3}{|c|}{ Intensity of chemoluminescence, $\mathrm{imp} / \mathrm{s}$} \\
\hline & \multirow{2}{*}{ Comparison group } & \multicolumn{2}{|c|}{ Dose, DL50 } \\
\hline & & $1 / 10$ & $1 / 100$ \\
\hline 10 & $560[555 ; 573]$ & $\begin{array}{c}999[884 ; 1056] \\
\mathrm{p}<0.001\end{array}$ & $\begin{array}{c}795[723 ; 845] \\
p<0.001\end{array}$ \\
\hline 20 & $544[480 ; 564]$ & $\begin{array}{c}1151[1084 ; 1245] \\
\mathrm{p}<0.001\end{array}$ & $\begin{array}{c}973[890 ; 1005] \\
\mathrm{p}<0.001 \\
\end{array}$ \\
\hline 30 & $534[489 ; 552]$ & $\begin{array}{c}1075[1012 ; 1123] \\
\mathrm{p}<0.001\end{array}$ & $\begin{array}{c}1001[873 ; 1045] \\
\mathrm{p}<0.001\end{array}$ \\
\hline 50 & $564[548 ; 603]$ & $\begin{array}{c}722[642 ; 888] \\
p<0.001\end{array}$ & $\begin{array}{c}1028[914 ; 1089] \\
\mathrm{p}<0.001\end{array}$ \\
\hline 60 & $546[526 ; 578]$ & $\begin{array}{c}489[421 ; 503] \\
p=0.008\end{array}$ & $\begin{array}{c}850[720 ; 934] \\
p<0.001\end{array}$ \\
\hline
\end{tabular}

Note: $p$ is the level of statistical significance in relation to the comparison group 
aging and cell biology. Together superoxide and nitric oxide can initiate arachidonate and lipid peroxidation associated with both cell signaling and cell killing, where the biological levels of these reactive oxygen species are precisely controlled by the SOD and nitric oxide synthase enzymes ${ }^{22}$. By taking into account the role of catalase in the processes of oxygenation, it can be anticipated that the decrease in its activity will contribute to the development of rat hypoxia in fluoride intoxication conditions, accumulation of hydrogen peroxide - the source of hydroxyl radical, the appearance of lipid hydroperoxides and oxide-modified proteins.

Early proposals suggesting that superoxide is non-toxic and that superoxide removal is not the biological role of SOD were unsupported by subsequent research. Likewise, the proposed phosphate inhibition of SOD was shown to be incorrect, agreeing with the structural analyses; the initial study reporting inhibition had mistakenly adjusted the ionic strength with sodium fluoride ${ }^{23-24}$. The detected increase in the activity of SOD in our research against the background of the decrease in the activity of catalase in the initial terms of SF action indicates an increase by several times in the rate of formation of hydrogen peroxide by the rate of its enzymatic utilization.

The overall mechanism by which SODs function has been called a "ping-pong“ mechanism as it involves the sequential reduction and oxidation of the metal center, with the concomitant oxidation and reduction of superoxide radicals at virtually diffusion controlled rates that generally include a $\mathrm{pH}$ range (approximately $\mathrm{pH}=5-9.5$ ) where the rate is unchanging $^{25}$. In general, a steady decline in the activity of SOD (after the 20th day of SF exposure) and catalase (in all observation periods), on the one hand, is an indicator of oxidative stress, and on the other hand, the antioxidant system as a stress-limiting system, such a result can be considered as its insufficiency, which contributes to the development of excessive stress-reaction ${ }^{26}$.

Thus, the obtained results indicate a manifestation of the physiological response of the body of rats to fluoride intoxication by activation of free radical oxidation. Prolonged fluoride loading leads to an excessive increase in the formation of free radicals in the body of rats and weakening of antioxidant defense. The result of such disruptions is the change in the physical and chemical properties of cell membranes, especially their barrier function, which causes the formation of pathological processes. Due to their physiological and biochemical features, brain tissue suffers from the excessive activation of free radical reactions most of all ${ }^{27-30}$.

\section{Conclusions}

Under conditions of long-term fluoride intoxication in the rat's brain, the expressed disruptions of free radical oxidation occur, which is reflected as the increase in the intensity of chemoluminescence of its homogenate and decrease in the activity of the antioxidant enzymes superoxide dismutase and catalase in the neocortex, which is a significant factor in the depletion of the adaptive capacity of the body. Reducing the intensity of a superweak luminescence on the 60th day of oral administration of SF to rats at a dose of 1/10 DL50 indicates a depletion of the energy potential of the substrate and the inadequate admission of free radicals of biological molecules to the oxidation system.

\section{Acknowledgements}

We thank all the members of the research team

\section{Compliance with Ethics Requirements:}

„The authors declare no conflict of interest regarding this article"

"The authors declare that all the procedures and experiments of this study respect the ethical standards in the Helsinki Declaration of 1975, as revised in 2008(5), as well as the national law."

„No funding for this study“

\section{References}

1. Fang YZ, Yang S, Wu G. Free radicals, antioxidants, and nutrition. Nutrition 2000; 18: 872-879.

2. Hall ED, Vaishnav RA, Mustafa AG. Antioxidant therapies for traumatic brain injury. Neurotherapeutics 2010; 7(1): 51-61.

3. Krishnamurthy P, Wadhwani A. Antioxidant enzymes and human health. Antioxidant enzyme. InTech; 2012.

4. Barja G. Free radicals and aging. Trends Neurosci 2004; 27: 595.

5. Zhu Y, Carvey PM, Ling Z. Age-related changes in glutathione and glutathione-related enzymes in rat brain. Brain Res 2006; 1090:35-44.

6. Kujoth GC, Hiona A, Pugh TD, et al. Mitochondrial DNA mutations, oxidative stress, and apoptosis in mammalian aging. Science 2005; 309:481.

7. Corpas FJ, Fernández-Ocaña A, Carreras A, et al. The expression of different superoxide dismutase forms is cell-type dependent in olive (Olea europaea L.) leaves. Plant Cell Physiol 2006; 47:984-94.

8. Lee J, Koo N, Min DB. Reactive oxygen species, aging, and antioxidative nutraceuticals. Compr Rev Food Sci F. 2004; 3: 21-33.

9. Weydert CJ, Cullen JJ. Measurement of superoxide dismutase, catalase and glutathione peroxidase in cultured cells and tissue. Nat Protoc 2010; 5: 51-66.

10. Dringen R. Oxidative and antioxidative potential of brain microglial cells. Antioxid Redox Signal 2005; 7:1223. 
11. Grigorova IA, Yeskin AR, Tikhonova LV, et al. The state of the oxidant-antioxidant system in patients with recurrent cerebral circulation disorders. Journal of Neurology. B.M. Mankovsky 2015; 3(1): 10-13. [Published in Russian]

12. Falletti O, Cadet J, Favier A, Douki T. Trapping of 4-hydroxynonenal by glutathione efficiently prevents formation of DNA adducts in human cells. Free Radic Biol Med 2007; 42(8): 1258-69.

13. Johnson F, Giulivi C. Superoxide dismutases and their impact upon human health. Mol Aspects Med 2005; 26:340-52.

14. Rahman K. Studies on free radicals, antioxidants, and co-factors. Clin Intervent Aging 2007; 2:219.

15. Migliore L, Coppede F. Environmental-induced oxidative stress in neurodegenerative disorders and aging. Mutat Res. 2009; 674:73-84.

16. Chung YH, Shin CM, Joo KM, et al. Immunohistochemical study on the distribution of nitrotyrosine and neuronal nitric oxide synthase in aged rat cerebellum. Brain Res 2002; 951: 316.

17. Morita M, Naito Y, Yoshikawa T. Plasma lipid oxidation induced by peroxynitrite, hypochlorite, lipoxygenase and peroxyl radicals and its inhibition by antioxidants as assessed by diphenyl-1-pyrenylphosphine. Redox Biol 2016; 8:127-135.

18. Khan RA, Khan MR, Sahreen S. Brain antioxidant markers, cognitive performance and acetylcholinesterase activity of rats: efficiency of Sonchus asper. Behav Brain Funct 2012; $8: 21$

19. Dayal S, Baumbach GL, Arning E, Bottiglieri T, Faraci FM, Lentz SR. Deficiency of superoxide dismutase promotes cerebral vascular hypertrophy and vascular dysfunction in hyperhomocysteinemia. PloS One 2017; 12:e0175732.
20. Rao AL, Bharani M, Pallavi V. Role of antioxidants and free radicals in health and disease. Adv Pharmacol Toxicol 2006; 7:29-38.

21. Gottfredsen RH, Larsen UG, Enghild JJ, Petersen SV. Hydrogen peroxide induce modifications of human extracellular superoxide dismutase that results in enzyme inhibition. Redox Biol 2013; 1:24-31.

22. Wang Y, Loake GJ, Chu C. Cross-talk of nitric oxide and reactive oxygen species in plant programed cell death. Front Plant Sci 2013; 4:314.

23. Bains M, Hall ED. Antioxidant therapies in traumatic brain and spinal cord injury. Biochim Biophys Acta 2012; 1822(5):675-84.

24. Lobo V, Patil A, Phatak A, Chandra N. Free radicals, antioxidants and functional foods: impact on human health. Pharmacogn Rev 2010; 4:118.

25. Giustarini D, Dalle-Donne I, Tsikas D, Rossi R. Oxidative stress and human diseases: origin, link, measurement, mechanisms, and biomarkers. Crit Rev Clin Lab Sci 2009; 46:241-281.

26. Pham-Huy LA, He H, Pham-Huy C. Free radicals, antioxidants in disease and health. Int J Biomed Sci: IJBS 2008;4:89.

27. Cui H, Kong Y, Zhang H. Oxidative stress, mitochondrial dysfunction, and aging. J Signal Transduct 2012; 2012: 646354.

28. Hayes J, Flanagan J, Jowsey I. Glutathione transferases. Annu Rev Pharmacol Toxicol 2005; 45: 51-88.

29. Asaduzzaman Khan M, Tania M, Zhang DZ, Chen HC. Antioxidant enzymes and cancer. Chinese J Cancer Res 2010; 22:87-92.

30. Liang H, Ran Q, Jang YC, et al. Glutathione peroxidase 4 differentially regulates the release of apoptogenic proteins from mitochondria. Free Radical Biol Med 2009; 47:312-320. 